\title{
Sobre esta edição
}

Caros leitores, a E-Compós traz, na sua última edição de 2014, um conjunto de textos com temáticas livres, que refletem um pouco do desenvolvimento da pesquisa no campo contemporâneo da Comunicação. No decorrer desse ano, a E-Compós recebeu mais de 100 textos para avaliação, de modo que 0 trabalho de seleção demandou labores de parte significativa dos membros do conselho editorial e do corpo de pareceristas. Os editores agradecem 0 empenho de todos em manter a excelência da revista. 0 agradecimento é dirigido também aos pesquisadores que enviaram os resultados de suas pesquisas, demonstrando o interesse que possuem na E-Compós.

Esta edição tem início com um conjunto de textos que refletem sobre o campo do audiovisual. 0 primeiro deles é $O$ menor $e$ o maior no cinema pessoal, de autoria de Roberta Veiga, que discute os modos como um tipo de cinema, de escrita pessoal e doméstica, pode evocar uma experiência, maior, coletiva, de forma a compreender como 0 autobiográfico pode fazer pensar a incorporação do outro e da história na constituição de si. Seguindo no âmbito da discussão, Mariana Baltar, no artigo Real sex, real lives - excesso, desejo e as promessas do real, demonstra possíveis diálogos entre o documentário e a pornografia na série Real People, Real Life, Real Sex, do realizador Tony Comstock. Já Gustavo Souza, no artigo 
O personagem no road movie documental brasileiro, busca apresentar as composições de personagem no road movie documental brasileiro, focando especificamente nos filmes Pachamama (Eryk Rocha, 2009) e Olhe pra mim de novo (Cláudia Priscila e Kiko Goifman, 2011). Em A Ambiguidade Homem/Animal em Mal dos Trópicos e a dimensão xamânica da Imagem, Henrique Codato nos oferece a possibilidade de entender $a$ experiência do espectador de cinema em nossos dias, revelando-se como uma arte em constante transformação e que se abre para a alteridade. Fechando esta primeira seção, A escada negra para o protagonismo branco: comédia, melodrama e retórica racial em A Dupla do Barulho (1953), de Pedro Vinícius Asterito Lapera, analisa a cadeia produtiva de A Dupla do Barulho (Carlos Manga, 1953), a fim de compreender a sua inserção no debate sobre relações raciais.

Quando uma notícia é parte da história: as mídias informativas e a identidade narrativa, de autoria de Bruno Leal, abre as discussões mais próprias ao campo das indústrias da informação e do entretenimento. Nesse sentido, aborda como a narratividade jornalística se articula com as mídias informativas em uma espécie de identidade narrativa e configurando sujeitos semióticos. Seguindo na perspectiva de foco no âmbito da informação e do entretenimento, o artigo A influência de youtubers no processo de decisão de espectadores, de Bruna Seibert Mota, Maíra Bittencourt, Pablo Moreno Fernandes Viana, demonstra a influência que os youtubers exercem sobre as práticas de consumo de quem assiste aos seus conteúdos a partir da análise dos comentários deixados sobre os vídeos. $A$ tormenta de um Crowdfunding de jogo brasileiro, de autoria de Cristiano Max Pereira Pinheiro, Eduardo Muller e Maurício Barth, avalia o processo de planejamento e execução da campanha de crowdfunding do jogo Tormenta - os Desafios dos Deuses, considerando-o pelo prisma da economia criativa. 
Por sua vez, A amizade no foco da notícia: relacionamentos interpessoais na mídia brasileira é um artigo que foca mais especificamente nos modos de narrar do jornalismo. Nele, os autores Luciana Teles Moura e Agnaldo Garcia demonstram como a amizade pode ser construída como uma forma de relacionamento positiva, que traz maior satisfação pessoal e garante a concessão de benefícios mútuos. Seguindo princípio semelhante, Renata Maria do Amaral analisa como o jornalismo gastronômico se insere na cultura de consumo contemporânea brasileira, recorrendo aos conceitos de hedonismo imaginativo, de Campbell; gosto, distinção e estilo de vida, de Bourdieu; e renovação do desejo pela moda, de Lipovetsky, no artigo Você tem fome de quê? Jornalismo gastronômico na cultura de consumo contemporânea brasileira. Robson Dias, em O estado da arte da pesquisa acadêmica sobre prêmios em Jornalismo, apresenta um panorama dos modos como as premiações em Jornalismo, encaradas como elementos constituintes da cultura profissional que incidem de forma indireta sobre o processo de produção da notícia, refletem tendências das últimas três décadas. Finalmente, Do convencer ao interagir: algumas reflexões sobre contextos e percursos da publicidade, de Cláudia Pereira e Amanda Antunes, trata do debate sobre os processos de transformação da narrativa publicitária brasileira ao longo de sua história

Carla Montuori Fernandes, em A narrativa ficcional e a representação dos fatos políticos na telenovela, destaca como a Rede Globo de Televisão relacionou temas políticos com a representação de teledramaturgia, na versão adaptada da telenovela Saramandaia, em 2013.

0 texto final é resultado da dissertação vencedora do prêmio COMPÓS 2014, de autoria de Márcio da Silveira Telles e Alexandre Rocha da Silva. Denomina-se Os tempos mortos 
do futebol na televisão e discorre como as imagens inseridas durante as pausas no esporte são importantes para a compreensão global da narrativa esportiva, conferindo sentido aos acontecimentos do futebol.

Por fim, Ideias: as 100 técnicas de criatividade é a resenha que Mauro Maia Laruccia faz nesta edição, comentando o trabalho de Guy Aznar, presidente da Associação Francesa para o Desenvolvimento da Criatividade.

Desejamos a todos uma excelente leitura!

Comissão Editorial E-Compós 